\title{
PATTERNS OF DISTRIBUTION AND ABUNDANCE OF LARVAL PHOSICHTHYIDAE (ACTINOPTERYGII, STOMIIFORMES) IN SOUTHEASTERN BRAZILIAN WATERS
}

\author{
Cássia Gôngora Goçalo*, Mario Katsuragawa and Ilson Carlos Almeida da Silveira
}

Instituto Oceanográfico da Universidade de São Paulo

(Praça do Oceanográfico, 191, 05508-120 São Paulo, SP, Brasil)

*Corresponding author: cabiol@bol.com.br

\begin{abstract}
A B S T R ACT
Horizontal and vertical distribution patterns and abundance of larval phosichthyids were investigated from oblique and depth-stratified towns off Southeastern Brazilian waters, from São Tomé cape $\left(41^{\circ} \mathrm{W}\right.$.; $22^{\circ} \mathrm{S}$.) to São Sebastião island $\left(45^{\circ} \mathrm{W}\right.$.; $24^{\circ} \mathrm{S}$.). The sampling was performed during two cruises (January/2002 - summer; August/2002 - winter). Overall 538 larvae of Phosichthyidae were collected during summer and 158 in the winter. Three species, Pollichthys mauli, Vinciguerria nimbaria and Ichthyioccoccus sp. occurred in the area, but Ichthyioccoccus sp. was extremely rare represented by only one specimen, caught in the oceanic region during the summer. Geographically, larval were concentrated in the oceanic region, and vertically distributed mainly between the surface and $80 \mathrm{~m}$ depth in the summer and winter. Larvae were more abundant during the night, performing a diel vertical migration in the water column. The results suggest that the meandering and eddies of Brazil Current play important role on the transport and distribution patterns of larval phosichthyids over the oceanic and neritic area in the Southeastern Brazil.
\end{abstract}

\section{RESUMO}

Padrões de distribuição horizontal e vertical e abundância de larvas de peixes de Phosichthyidae foram examinados a partir de arrastos oblíquos e estratificados em águas do Sudeste Brasileiro, entre cabo de São Tomé $\left(41^{\circ} \mathrm{W}\right.$.; $22^{\circ} \mathrm{S}$.) e a ilha de São Sebastião $\left(45^{\circ} \mathrm{W}\right.$.; $24^{\circ} \mathrm{S}$.). A amostragem foi realizada durante dois cruzeiros (Janeiro/2002 - verão; Agosto/2002 - inverno). Foi coletado um total de 538 larvas de Phosichthyidae durante o verão e 158 no inverno. Três espécies, Pollichthys mauli, Vinciguerria nimbaria e Ichthyioccoccus sp. ocorreram na área, mas Ichthyioccoccus sp. foi extremamente rara representada somente por uma larva, capturada na região oceânica durante o verão. Geograficamente, as larvas estiveram concentradas na região oceânica e verticalmente entre a superfície e $80 \mathrm{~m}$ de profundidade nos cruzeiros de verão e inverno. As larvas foram mais abundantes durante a noite, apresentando uma migração vertical diária na coluna d'água. Os resultados sugerem um importante papel dos meandramentos e vórtices da Corrente do Brasil no transporte e padrões de distribuição das larvas dos Phosichthyidae nas áreas oceânica e nerítica do sudeste brasileiro.

Descriptors: Phosichthyidae, Larval fish, Distribution, Tropical water mass, Brazil current.

Descritores: Phosichthyidae, Larva de peixe, Distribuição, Massa de água tropical, Corrente do Brasil.

\section{INTRODUCTION}

Phosichthyidae are mesopelagic fishes, known as lightfishes due to the bioluminescence produced by special cells (photophores) located along the ventral region of the body (FAHAY, 1983; SCHAEFER et al., 1986). These fishes are also known for performing active diel vertical migration (CLARKE, 1971) from the mesopelagic to the epipelagic zones. Mesopelagic fish are dominant in the oceanic region both in number of species and individuals, and represent one of the most important links in the food chain in the marine ecosystem
(TORTONESE, 1970; LOEB, 1979). They are important in the diet of pelagic predators such as Coryphaena hippurus, Alepisaurus ferox, Alopias pelagicus and Thunnus albacares (ZAVALA CAMIN, 1978; MOTEKI et al., 2001) and are recognized as contributing to the distribution of tuna in the water column (MARCHAL; LEBOURGES, 1996; LEBOURGES-DHAUSSY et al., 2000). They feed on zooplankton, squid and other fish (LERMAN, 1986).

Larvae of mesopelagic fishes occur all year round in high abundance, mainly in the offshore region (MATSUURA et al., 1980). Phosichthyidae 
species are oviparous and pelagic spawning, with planktonic eggs and larvae (SANZO, 1930, 1931; AHLSTROM; COUNTS, 1958; AHLSTROM; BALL, 1984). The planktonic fish eggs and larvae can be transported in the sea by oceanic circulation, so that their distribution and abundance are affected by many biological processes including ontogeny, the concentration and varied size of their food, intra and inter specific competition, and physical processes in the water column such as temperature, light intensity, oceanic fronts, tides, winds, currents, upwelling, thermoclines and haloclines (BLAXTER, 1973; LASKER, 1975; LOEB, 1979; HEMPEL, 1979; FORTIER; LEGGETT, 1983; PHONLOR, 1984; NEILSON; PERRY, 1990).

Acknowledge of the distribution patterns of larval fish and of environmental factors is very important for the understanding of the ecological processes that influence larval abundance in the ocean (BRODEUR; RUGEN, 1994). Studies have shown that Phosichthyidae larvae are distributed, preferentially, in the oceanic region, in warm and saline waters, with higher abundance between 0 and $100 \mathrm{~m}$ depth, in the Gulf of California, the East China Sea, off the coasts of Japan, Angola and in the Canary Islands (AHLSTROM, 1959; OZAWA, 1976; JOHN et al., 2001; RODRIGUEZ et al., 2004; FUKUI; KURODA, 2005; OKAZAKI; NAKATA, 2007; MOYANO et al., 2009). Some studies undertaken in
Brazilian waters, e.g. BONECKER AND HUBOLD (1990); NONAKA ET AL. (2000) and BONECKER ET AL. (2006), have shown that Phosichthyidae larvae occur mainly in the offshore region, their distribution being associated with cold water in the Abrolhos region (Bahia) but with a warmer water mass and mixed water in the southernmost area. However, information in the literature about the distribution of this group in Brazil is still scant. The present study aims to investigate the horizontal and vertical distribution and the abundance of Phosichthyidae larvae in relation to environmental factors in the region between São Tomé cape and São Sebastião island, in southeastern Brazil.

\section{Material ANd Methods}

Two cruises were carried out off southeastern Brazil by the R/V "Prof. W. Besnard", from São Tomé cape $\left(41^{\circ} \mathrm{W}\right.$.; $22^{\circ} \mathrm{S}$.) to São Sebastião island $\left(45^{\circ} \mathrm{W}\right.$.; $24^{\circ} \mathrm{S}$.). The sampling plan for the summer cruise (January, 2002) covered 72 oceanographic stations distributed on 14 transects (R1 to R14) and that for the winter cruise (August, 2002) 66 stations on 13 transects (R1 to R13), the station interval was 20 nautical miles (Fig. 1). The collection was performed in all the periods of day (dawn, day, dusk and night).

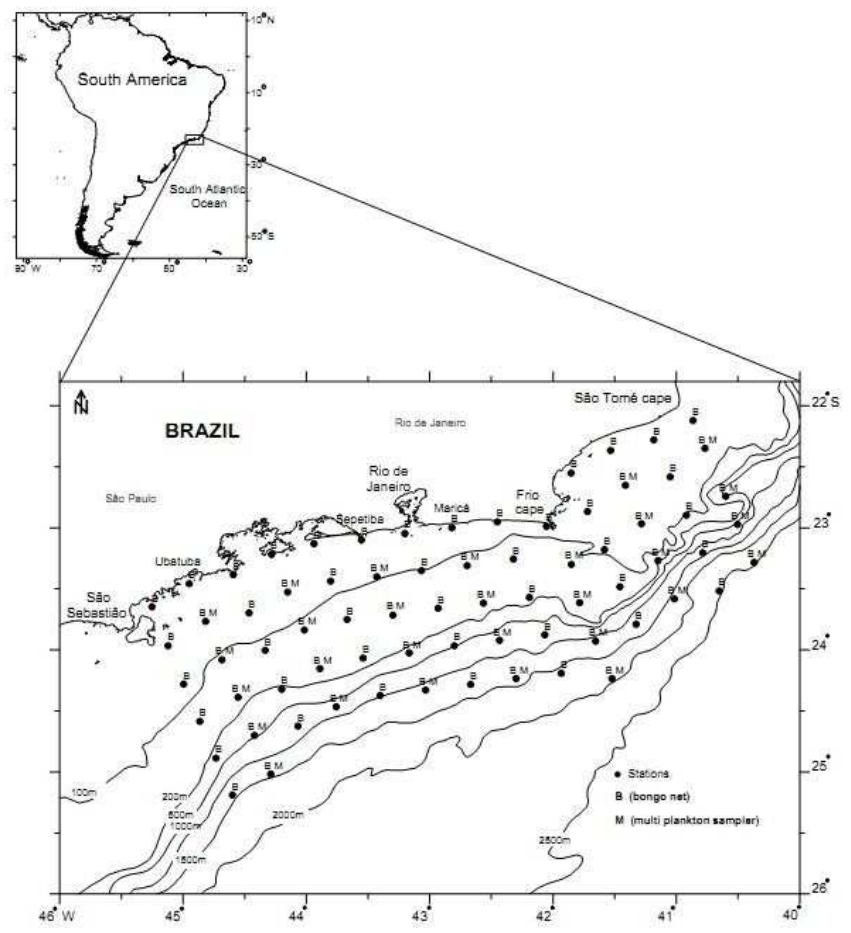

Fig. 1. Map of sampling stations performed in January/2002 and August/2002 between São Tomé cape (Rio de Janeiro) and São Sebastião island (São Paulo) in the southeastern coast of Brazil. Where there is letter $\mathbf{B}$ refers to ichthyoplankton collection stations with bongo net and $\mathbf{M}$ with multi plankton sampler. 
A CTD (conductivity-temperature depth profiler) cast provided hydrographic data for each station. The temperature-salinity diagrams (T-S) provided the identification of water masses (EMÍLSSON, 1961; MIRANDA, 1985).

Two sampling methods were used to collect ichthyoplankton: 1) oblique tows with a $61 \mathrm{~cm}$ bongo fitted with 0.333 and $0.506 \mathrm{~mm}$ mesh nets (SMITH; RICHARDSON, 1977), of which only samples from the $0.333 \mathrm{~mm}$ mesh net were used in the present study; and 2) stratified tows with a $1 \mathrm{~m}^{2}$ multi-plankton sampler (MPS), equipped with 5 nets of $0.300 \mathrm{~mm}$ mesh size, to target $20 \mathrm{~m}$ depth layers. The volume of water filtered was measured with a flowmeter mounted at the mouth of each net. Plankton samples were preserved aboard in $4 \%$ buffered formalin seawater.

Larvae were examined under a stereomicroscope and the identification of Phosichthyidae species was based on descriptions from the literature (AHLSTROM; COUNTS, 1958; GREY, 1964; FAHAY, 1983, 2007; WATSON, 1996; BONECKER et al., 2006; RICHARDS, 2006). The occurrence frequency of larvae (\%) was calculated based on the Guille (1970) expression: $[\mathrm{F}=$ $(\mathrm{Ni} / \mathrm{Nt}) .100)]$ Where, $\mathrm{F}=$ occurrence frequency, $\mathrm{Ni}=$ the number of positive stations of the taxonomy category $\mathrm{i}$, and $\mathrm{Nt}=$ the total number of stations. Abundance of larvae (larvae. $\mathrm{m}^{-2}$ ) of bongo samples was estimated to represent the horizontal distribution, using Tanaka (1973) expression: $\left[\mathrm{Y}=(\mathrm{d} . \mathrm{x}) \mathrm{V}^{-1}\right]$ where $\mathrm{Y}=$ number of larvae per $\mathrm{m}^{2}$ of sea surface, $\mathrm{d}=$ depth of haul (m), $\mathrm{x}=$ number of larvae taken on sampling, and $\mathrm{V}=$ volume of filtered water $\left(\mathrm{m}^{3}\right)$ measured by flowmeter. Larval density (larvae. $100 \mathrm{~m}^{-3}$ ) of MPS, describing larval distribution in different layers, was calculated by the ratio between the number of larvae taken in the sample and the volume of water filtered $\left(\mathrm{m}^{3}\right)$ as measured by flowmeter, multiplied by 100 (HENSEN, 1887).

Larvae were measured by a digitizing tablet, a stereomicroscope equipped with a drawing tube, and the size-frequency distributions obtained for $0.5 \mathrm{~mm}$ classes, and were categorized as belonging to the preflexion, flexion, or postflexion stage, according to the state of notochord flexion (AHLSTROM; BALL, 1954). The body length (BL) of the preflexion and flexion larvae was measured from the tip of the snout to the end of the notochord (equivalent to notochord length, NL), and of postflexion larvae from the tip of the snout to the posterior edge of the developing hypurals (equivalent to standard length, SL).

Based on previous studies (KATSURAGAWA; MATSUURA, 1992; LOPES et al., 2006), the study area was divided into three subareas parallel to the coast: a) coastal (from the coast to the $100 \mathrm{~m}$ isobath); b) intermediate (from $100 \mathrm{~m}$ to
$200 \mathrm{~m}$ isobaths), and c) oceanic (deeper than the 200 $\mathrm{m}$ isobath). The non-parametric Mann-Whitney U-test was used to evaluate differences in larval abundance and density as between summer and winter and the different sub-areas. Differences between layers were examined by using a Kruskal-Wallis test and Dunn test a posteriori (ZAR, 1999). A multivariate statistical analysis (Redundancy Analysis - RDA), in the CANOCO software package (TER BRAAK; SMILAUER, 2002), was used to investigate the contribution of the environmental factors to the distribution and density of larvae and their respective development stages. A Monte Carlo test was used to test the significance of the contribution of the environmental variables to the biological data.

\section{RESULTS}

\section{Oceanographic Conditions}

The mean water temperature for all the study area, from surface to $200 \mathrm{~m}$ depth, was significantly higher (Mann-Whitney U-test, $P<0.0001$ ) in the summer $\left(20.33^{\circ} \mathrm{C}\right.$; sd $\left.=3.79\right)$ than in the winter $\left(20.28^{\circ} \mathrm{C} ; \mathrm{sd}=2.73\right)$. Concerning the salinity, the mean observed during the summer was 36.24 (sd = $0.63)$ and that during the winter $36.14(\mathrm{sd}=0.73)$, indicating significantly greater salinity in the summer according to a Mann-Whitney U-test $(P<0.0001)$ (Table 1).

During the summer the water column was strongly stratified, ranging from $24.31^{\circ} \mathrm{C}(\mathrm{sd}=2.21)$ at the $0-20 \mathrm{~m}$ layer to $19.62^{\circ} \mathrm{C}(\mathrm{sd}=2.90)$ at the $80-100$ $\mathrm{m}$ layer. A significant difference was observed between the upper layers $(0-40 \mathrm{~m})$ and the $60-100 \mathrm{~m}$ layer (Kruskal-Wallis test, $P<0.05$ ). On the other hand, during the winter the water column was relatively homogeneous, with the temperature ranging from $22.63^{\circ} \mathrm{C}(\mathrm{sd}=0.82)$ at the $0-20 \mathrm{~m}$ layer to $20.22^{\circ} \mathrm{C}(\mathrm{sd}=2.53)$ at the $80-100 \mathrm{~m}$ layer $($ Table 1$)$. The salinity of the water column was homogeneous, no significant differences being observed between layers in the summer and winter (Kruskal-Wallis test, $P>0.05)$. In the summer, the salinity presented mean $=36.37(\mathrm{sd}=0.57)$ at the $0-20 \mathrm{~m}$ layer and $36.33(\mathrm{sd}=$ 0.58 ) at the $80-100 \mathrm{~m}$ layer and in the winter, mean $=$ $36.08(\mathrm{sd}=0.85)$ at the $0-20 \mathrm{~m}$ layer and $36.49(\mathrm{sd}=$ 0.56 ) at the $80-100$ m layer.

Geographically, during the summer, the oceanic waters was significantly warmer (mean = $\left.21.08^{\circ} \mathrm{C}, \mathrm{sd}=3.59\right)$ than the coastal waters (mean $=$ $19.37^{\circ} \mathrm{C}$ sd $\left.=4.01\right)$ and intermediate waters (mean $=$ $19.30^{\circ} \mathrm{C}$, sd $\left.=3.72\right)$ (Mann-Whitney U-test, $P<$ 0.0001 ), but during the winter, the coastal (mean = $20.84^{\circ} \mathrm{C}$, sd $=1.95$ ) and oceanic regions (mean $=$ $20.53^{\circ} \mathrm{C}, \mathrm{sd}=2.85$ ) were significantly warmer than the intermediate region $\left(\right.$ mean $=19.65^{\circ} \mathrm{C}$, sd $\left.=2.76\right)$ 
(Mann-Whitney U-test, $P<0.0001$ ). The salinity was significantly lower (Mann-Whitney U-test, $P<$ 0.0001 ) in the coastal region (mean $=35.68$, $\mathrm{sd}=$ 0.62 ), than in the intermediate $($ mean $=36.03$, $\mathrm{sd}=$ 0.54 ), and oceanic regions (mean $=36.48$, sd $=0.56$ ) during the summer and the same occurred in the winter $($ mean $=35.39, \mathrm{sd}=0.94$ in the coastal; mean $=$ 36.05 , sd $=0.49$ in the intermediate and mean $=36.47$, sd 0.57 in the oceanic regions) (Table 2).

The T-S diagrams (Fig. 2) indicated the influence and interactions of three water masses in the area: Tropical Water (TW), South Atlantic Central
Water (SACW) and Coastal Water (CW). The Tropical water mass occupied the layer between the surface and $100 \mathrm{~m}$ depth, mainly in the oceanic region. In the deep layer (> 100m depth) values below $18^{\circ} \mathrm{C}$ and salinity between 35 and 36 were registered, indicating the presence of the SACW mass. The SACW was also found at the surface in the coastal region, between Frio cape and Guanabara bay (RJ) region, indicating a coastal upwelling event. In the southern coastal area the temperature was about $20^{\circ} \mathrm{C}$ and salinity 34 during both summer and winter, indicating the presence of a $\mathrm{CW}$ mass.

Table 1. Temperature $\left({ }^{\circ} \mathrm{C}\right)$ and salinity registered during the summer and winter in southeastern Brazilian waters. Minimum, maximum, mean and standard deviation (sd) estimated for the water column (from surface to $200 \mathrm{~m}$ depth) and strata sampled by multi-plankton sampler (from zero to $100 \mathrm{~m}$ depth).

\begin{tabular}{lc|c|c|c|c|c|c|c|cc}
\hline \hline \multicolumn{1}{c}{} & \multicolumn{9}{c}{ Temperature ${ }^{\mathbf{O}} \mathbf{c}$} \\
Season & Stratum & \multicolumn{1}{c}{ minimum } & \multicolumn{1}{c}{ maximum } & \multicolumn{1}{c}{ mean } & \multicolumn{1}{c}{ sd } & \multicolumn{1}{c}{ minimum } & \multicolumn{1}{c}{ maximum } & Mean & sd \\
\hline \multirow{5}{*}{ Summer } & $\mathbf{0 - 2 0 0 ~ m}$ & 13.08 & 27.64 & 20.33 & 3.79 & 33.42 & 37.24 & 36.24 & 0.63 \\
& $\mathbf{0 - 2 0 m}$ & 15.52 & 26.51 & 24.31 & 2.21 & 34.65 & 37.01 & 36.37 & 0.57 \\
& $\mathbf{2 0 - 4 0 m}$ & 13.77 & 26.39 & 22.29 & 3.46 & 35.20 & 37.09 & 36.50 & 0.52 \\
& $\mathbf{4 0 - 6 0 m}$ & 13.53 & 26.15 & 21.26 & 3.35 & 35.22 & 37.23 & 36.52 & 0.56 \\
& $\mathbf{6 0 - 8 0 m}$ & 13.08 & 25.18 & 20.21 & 3.29 & 35.18 & 37.24 & 36.42 & 0.61 \\
& $\mathbf{8 0 - 1 0 0 m}$ & 14.15 & 23.67 & 19.62 & 2.90 & 35.31 & 37.24 & 36.33 & 0.58 \\
& $\mathbf{0 - 2 0 0} \mathbf{m}$ & 14.11 & 24.54 & 20.28 & 2.73 & 33.12 & 37.39 & 36.14 & 0.73 \\
& $\mathbf{0 - 2 0 m}$ & 20.44 & 24.45 & 22.63 & 0.82 & 33.88 & 37.39 & 36.08 & 0.85 \\
& $\mathbf{2 0 - 4 0 m}$ & 19.31 & 24.48 & 22.51 & 1.05 & 34.10 & 37.39 & 36.42 & 0.75 \\
& $\mathbf{4 0 - 6 0 m}$ & 17.87 & 24.54 & 21.79 & 1.75 & 34.29 & 37.39 & 36.61 & 0.59 \\
& $\mathbf{6 0 - 8 0 m}$ & 16.57 & 23.63 & 20.99 & 2.10 & 35.72 & 37.38 & 36.60 & 0.48 \\
& $\mathbf{8 0 - 1 0 0 m}$ & 15.68 & 23.13 & 20.22 & 2.53 & 35.57 & 37.37 & 36.49 & 0.56 \\
\hline
\end{tabular}

Table 2. Temperature $\left({ }^{\circ} \mathrm{C}\right)$ and salinity registered during the summer and winter by region in southeastern Brazilian waters. Minimum, maximum, mean and standard deviation (sd) estimated for the water column (from surface to $200 \mathrm{~m}$ depth).

\begin{tabular}{c|c|cccc|cccc}
\hline \hline \multicolumn{1}{c}{} & \multicolumn{9}{c}{ Temperature ${ }^{\circ} \mathbf{C}$} \\
\hline Season & region & minimum & maximum & mean & sd & minimum & maximum & mean & Sd \\
\hline \multirow{3}{*}{ Summer } & Coastal & 13.53 & 27.64 & 19.37 & 4.07 & 33.42 & 37.18 & 35.68 & 0.62 \\
& Intermediary & 13.08 & 26.61 & 19.30 & 3.72 & 34.92 & 37.17 & 36.03 & 0.54 \\
& Oceanic & 13.26 & 26.54 & 21.08 & 3.59 & 35.22 & 37.24 & 36.48 & 0.56 \\
& Coastal & 14.11 & 23.67 & 20.84 & 1.95 & 33.12 & 37.04 & 35.39 & 0.94 \\
\multirow{3}{*}{ Winter } & Intermediary & 14.58 & 23.48 & 19.65 & 2.76 & 34.19 & 37.07 & 36.05 & 0.49 \\
& Oceanic & 14.21 & 24.54 & 20.53 & 2.85 & 35.35 & 37.39 & 36.47 & 0.57 \\
\hline
\end{tabular}



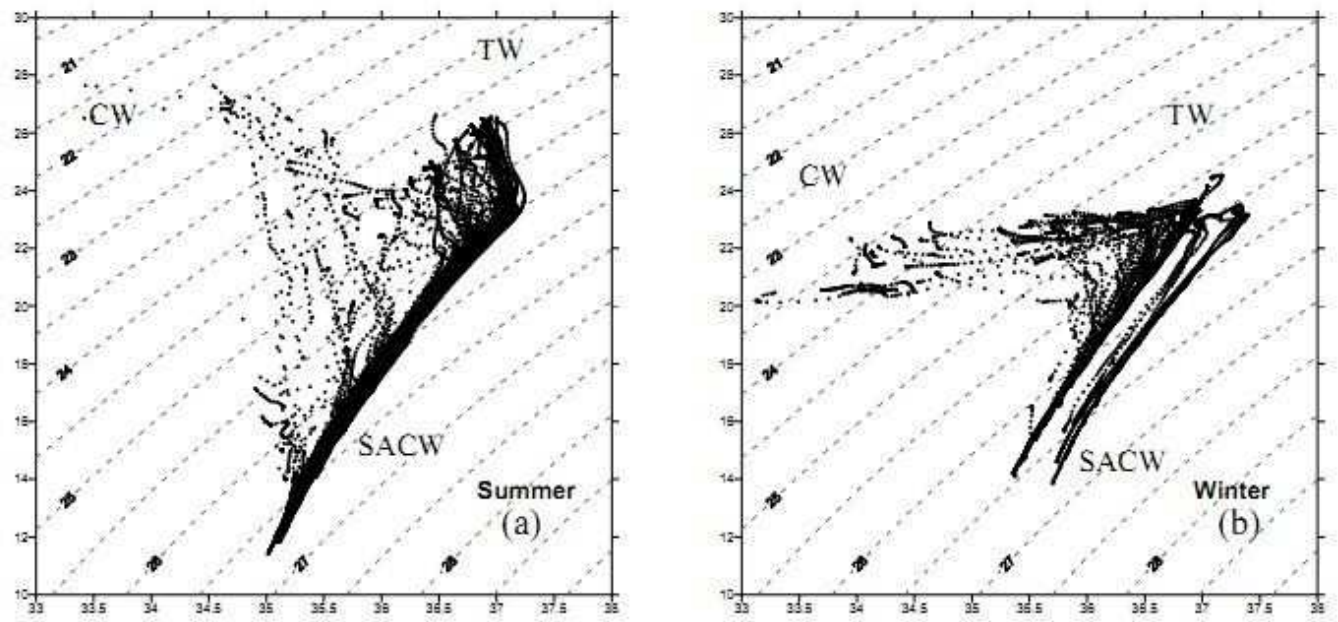

Fig. 2. Temperature-Salinity diagrams (T-S) of the total oceanographic stations realized during the summer (a) and winter (b) cruises, in 2002. Where TW refers to Tropical Water mass $\left(>20^{\circ} \mathrm{C}\right.$ and $\left.>36\right), \mathrm{SACW}$ refers to South Atlantic Central Water mass $\left(<20^{\circ} \mathrm{C}\right.$ e salinity between 35 and 36$)$ and $\mathrm{CW}$ refers to Coastal Water mass $\left(>20^{\circ} \mathrm{C}\right.$ and $\left.<34\right)$.

Larval Abundance and Horizontal Distribution Bongo Net Samples

A total of 411 (summer) and of 139 (winter) larvae of Phosichthyidae were collected with the bongo net. These amounts corresponded to $c a$. $2 \%$ of the total fish larvae sampled each season $(14,379$ in the summer and 7,828 in the winter). Two phosichthyid species occurred in the samples, Pollichthys mauli and Vinciguerria nimbaria, P. mauli being predominant $(62 \%$ of total Phosichthyidae in the summer and $54 \%$ in the winter). Larval $V$. nimbaria accounted for $25 \%$ of total phosichthyids in the summer and $45 \%$ in the winter.

The occurrence frequency of $P$. mauli was $50 \%$ in the summer and $45 \%$ in the winter. No significant difference was recognized in the abundance between these seasons (mean $=2.64$ larvae. $\mathrm{m}^{-2} ; \mathrm{sd}=$ 7.42 , in the summer and mean $=0.95$ larvae $\cdot \mathrm{m}^{-2} ; \mathrm{sd}=$ 2.61 , in the winter) (Mann-Whitney U-test, $P>0.05$ ). Larvae were widely distributed in the study area, but higher abundance was observed in the intermediate sub-area in the summer $\left(102.65\right.$ larvae. $\left.^{-2}\right)$, followed by the oceanic sub-area ( 85.29 larvae. $\left.\mathrm{m}^{-2}\right)$, while in the coastal sub-area the abundance was significantly lower $\left(1.82\right.$ larvae. $\left.\mathrm{m}^{-2}\right)$ (Kruskal-Wallis test, $\left.P<0.05\right)$. In the winter, higher abundance was estimated in the oceanic region (36.56 larvae. $\left.\mathrm{m}^{-2}\right)$, followed by the intermediate sub-area (22.70 larvae. $\left.\mathrm{m}^{-2}\right)$, both significantly different from the coastal region (3.71 larvae. ${ }^{-2}$ ) (KruskalWallis test, $P<0.05$ ) (Fig. 3).

The occurrence frequency of $V$. nimbaria was higher in the summer $(29 \%)$ than in the winter
(22\%), but no significant difference was observed in the abundance between the seasons (mean $=1.08$ larvae. $\mathrm{m}^{-2} ; \mathrm{sd}=2.79$, in summer and mean $=0.82$ larvae. $\mathrm{m}^{-2} ; \mathrm{sd}=1.92$, in the winter) (Mann-Whitney Utest, $P>0.05)$. Concerning the horizontal distribution, the result suggests that higher larval concentrations either for $P$. mauli or $V$. nimbaria tended to be observed far offshore (Fig. 3). The larval concentrations were significantly higher in the oceanic region (50.56 larvae. ${ }^{-2}$ in the summer and 38.80 larvae. $\mathrm{m}^{-2}$ in the winter) than in the coastal region (1.72 larvae. $\mathrm{m}^{-2}$ in the summer and 0.48 larvae. $\mathrm{m}^{-2}$ in the winter) (Kruskal-Wallis test, $P<0.05$ ).

\section{Larval Density and Vertical Distribution - MPS Samples}

A total of 127 (summer) and of 19 (winter) larvae of Phosichthyidae were collected with MPS. Three species were identified: P. mauli, V. nimbaria and Ichthyioccoccus sp., but Ichthyioccoccus sp. was extremely rare with only one specimen caught in the 20-40 m depth layer in the oceanic region during the summer. Larval $P$. mauli predominated in summer (65\% of total Phosichthyidae), whereas $V$. nimbaria larvae were predominant in the winter $(57 \%$ of total Phosichthyidae). P. mauli occurred at $60 \%$ of the oceanographic stations on the summer cruise and $14 \%$ in the winter, but the summer mean density of 3.37 larvae. $100 \mathrm{~m}^{-3}(\mathrm{sd}=7.25)$ was not significantly different from that observed in the winter of 0.33 larvae. $100 \mathrm{~m}^{-3}$ (sd = 1.61) (Mann-Whitney U-test, $P$ > $0.05)$. 

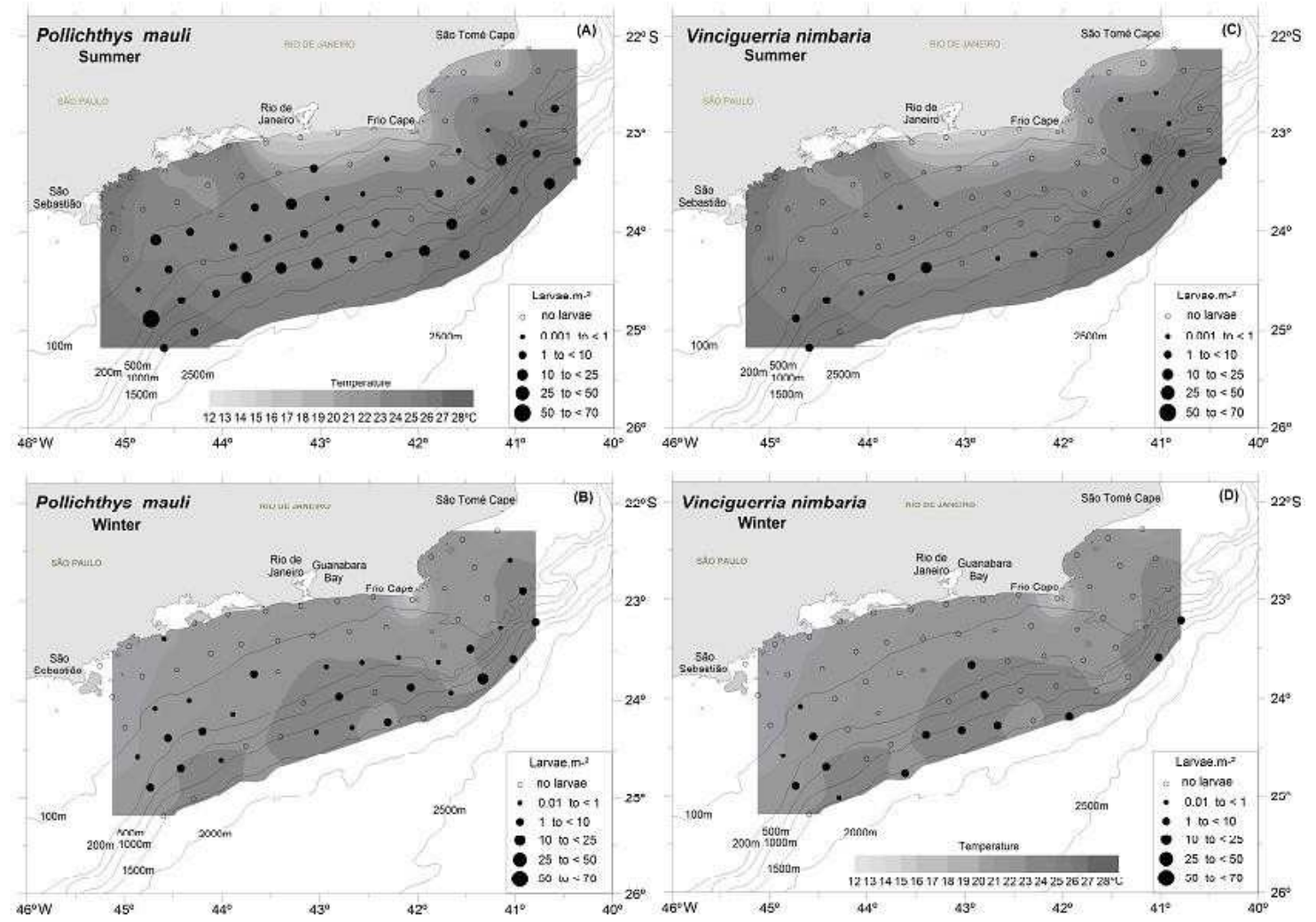

Fig. 3. Horizontal distribution of Pollichthys mauli in the summer (a) and in the winter (b); horizontal distribution of Vinciguerria nimbaria larvae during the summer (c) and winter (d) cruises in 2002, between São Tomé cape (RJ) and São Sebastião island (SP). Where $\mathbf{N}$ is the total number of larvae collected and the abundance larvae is estimated in larvas. $\mathrm{m}^{-2}$. Temperature registered to $10 \mathrm{~m}$ depth.

Larval $P$. mauli occurred in all layers sampled in the summer, with higher density estimated in the $60-80 \mathrm{~m}$ layer (mean of 6.87 larvae. $100 \mathrm{~m}^{-3} ; \mathrm{sd}=$ 11.41). In the winter, larvae occurred only between 20 and $60 \mathrm{~m}$ depths, of which the 20-40 m layer was extremely poor with only 2 larvae collected, whereas the mean density estimated for the 40-60 m layer was 1.16 larvae. $100 \mathrm{~m}^{-3}(\mathrm{sd}=2.84)$ but no significant difference was observed between layers in either season (Kruskal-Wallis test, $P>0.05$ ) (Figs 4 and 5).

The occurrence frequency of larval $V$. nimbaria was $25 \%$ on both the cruises, based on the MPS collections. Larval abundance in the summer was 0.84 larvae. $100 \mathrm{~m}^{-3}(\mathrm{sd}=3.51)$ and in the winter 0.51 larvae. $100 \mathrm{~m}^{-3}$ (sd $\left.=3.04\right)$, no significant difference being recognized in the density between seasons (Mann-Whitney U-test, $P>0.05$ ). This species was absent in the 80-100 m layer in both seasons. Higher density was estimated in the surface layer $(0-20 \mathrm{~m})$ in the summer $\left(\right.$ mean $=1.33$ larvae $100 \mathrm{~m}^{-3}$, sd $=3.27$ ) and from 20 to $40 \mathrm{~m}$ depth in the winter $($ mean $=1.65$ larvae. $100 \mathrm{~m}^{-3}$, sd $=6.21$ ), no significant differences being observed among layers (Kruskal-Wallis test, $P>$ 0.05) (Figs 4 and 6).

\section{Larval Length Frequency}

The size of $P$. mauli larvae ranged from 3 to $25 \mathrm{~mm}$, indicating the presence of all the early developmental stages. About $60 \%$ were in postflexion $(>7 \mathrm{~mm} \mathrm{SL}$ ) in the summer and winter. The larvae of 3-5 $\mathrm{mm}$ NL were in preflexion stage and 5-7 $\mathrm{mm} \mathrm{SL}$ in the flexion stage. Although no significant (MannWhitney U-test, $P>0.05$ ) differences were observed in the size-frequency larvae among regions, in general larvae larger than $15 \mathrm{~mm} \mathrm{SL}$ tended to occur predominantly in the shallower stations of the intermediate sub-area, while the smaller larvae (3-4 $\mathrm{mm} \mathrm{NL}$ ) occurred in the oceanic region, mainly in the summer. The most frequent size classes in the oceanic 
region were of 5.75 and $6.25 \mathrm{~mm}$ in the summer and of 4.75 and $6.25 \mathrm{~mm}$ in the winter. In the intermediate sub-area the 5.75 and $9.25 \mathrm{~mm}$ size classes predominated in the summer, and the $10.75 \mathrm{~mm}$ class predominated in the winter (Fig. 7).
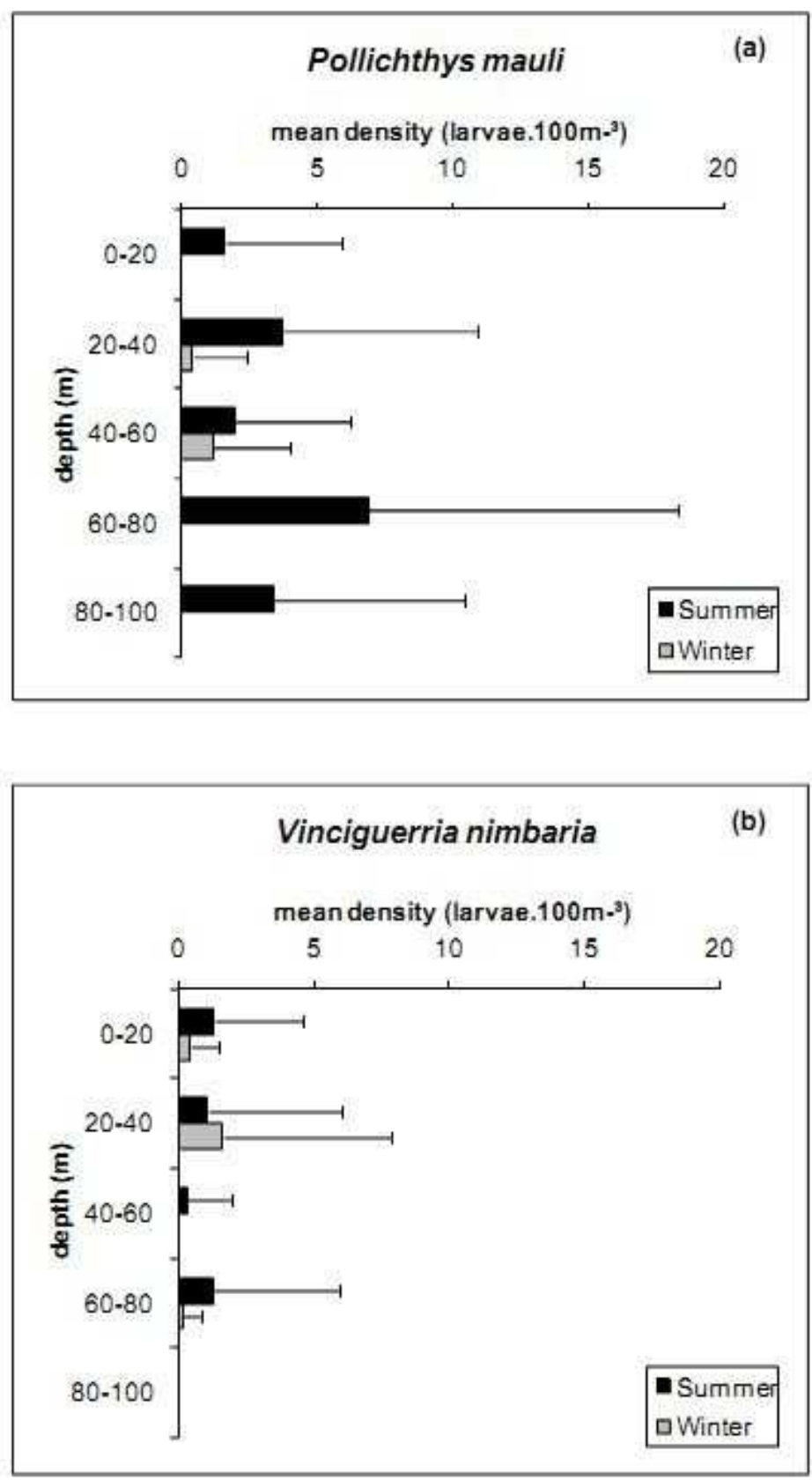

Fig. 4. Mean density of $P$. mauli and $V$. nimbaria fish larvae estimated to each layer sampled by multi plankton sampler (MPS) in the oceanographic stations, during the summer and winter cruises, in 2002. The density is expressed in larvae $100 \mathrm{~m}^{-3}$ and error bars are standard deviation about the mean density. 

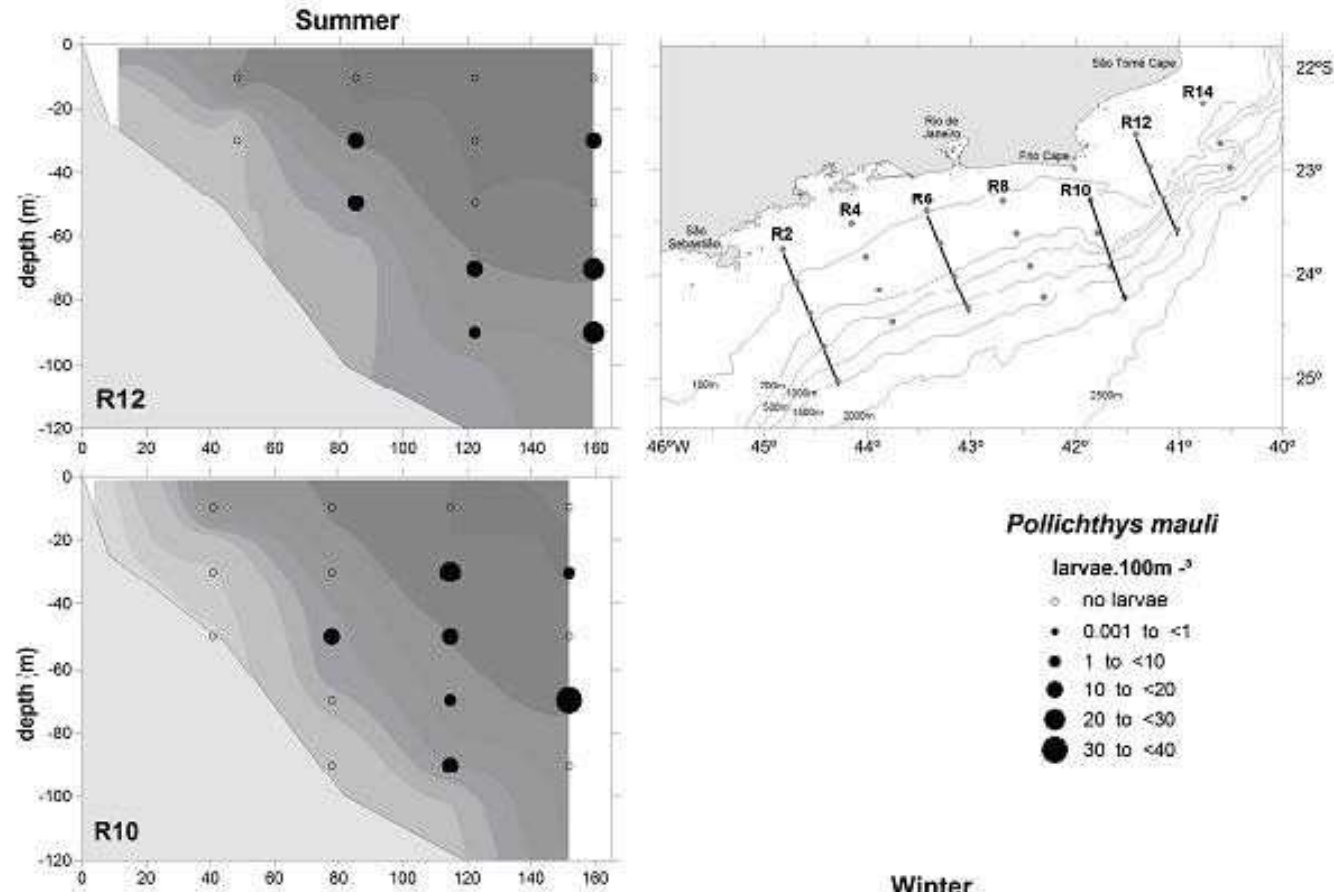

\section{Pollichthys maul}

larvae. $100 \mathrm{~m}^{-3}$

- no larvae

- 0001 to $<1$

- 1 ta $<10$

- 10 to $<20$

20 to $<30$

30 to $<40$
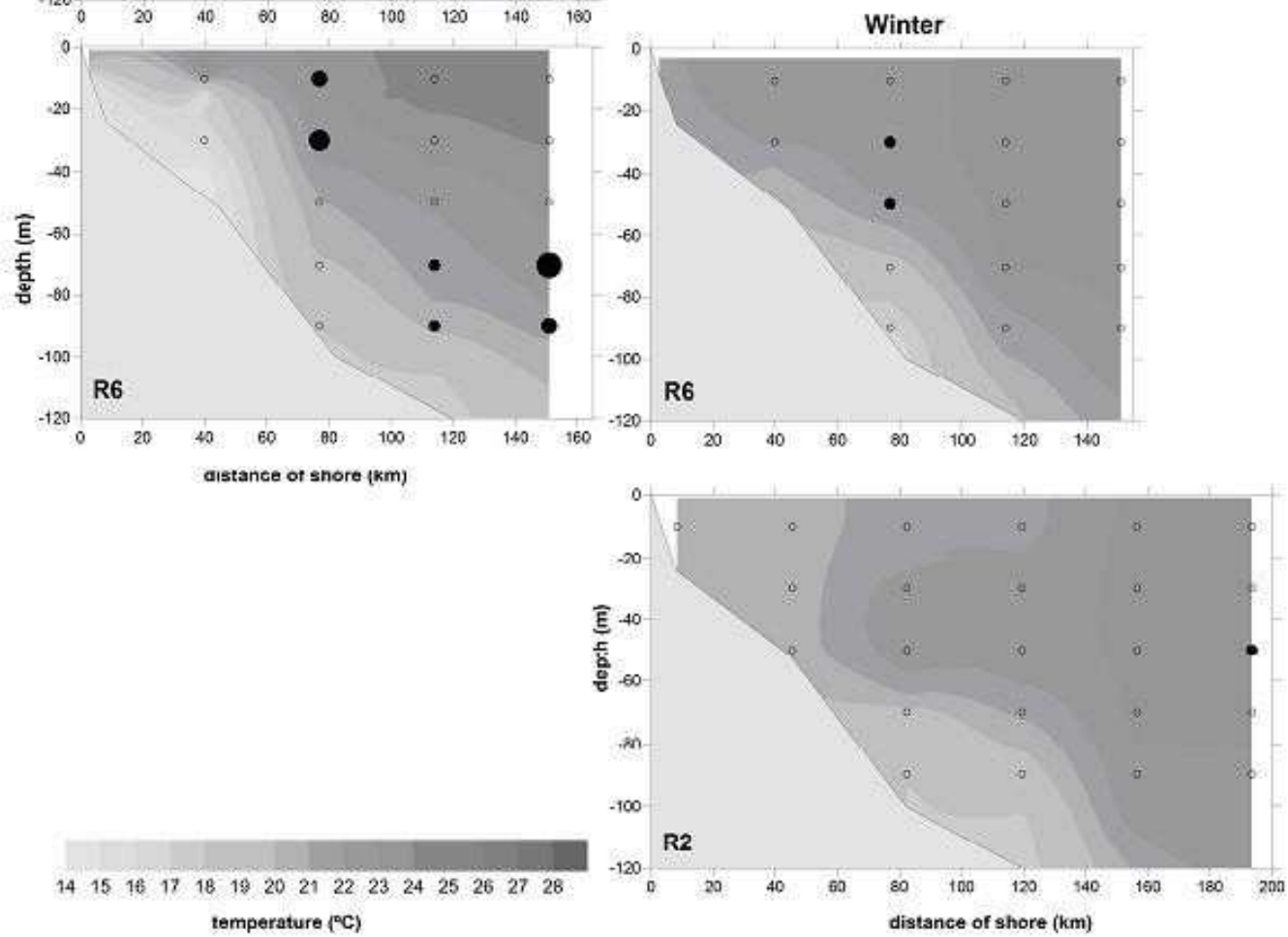

Fig. 5. Vertical profiles of temperature $\left({ }^{\circ} \mathrm{C}\right)$ and vertical distribution of $P$. mauli larvae on transect perpendicular to Brazilian coast $(\mathrm{R})$ during the summer and winter, 2002. The density is expressed in larvae. $100 \mathrm{~m}^{-3}$. 

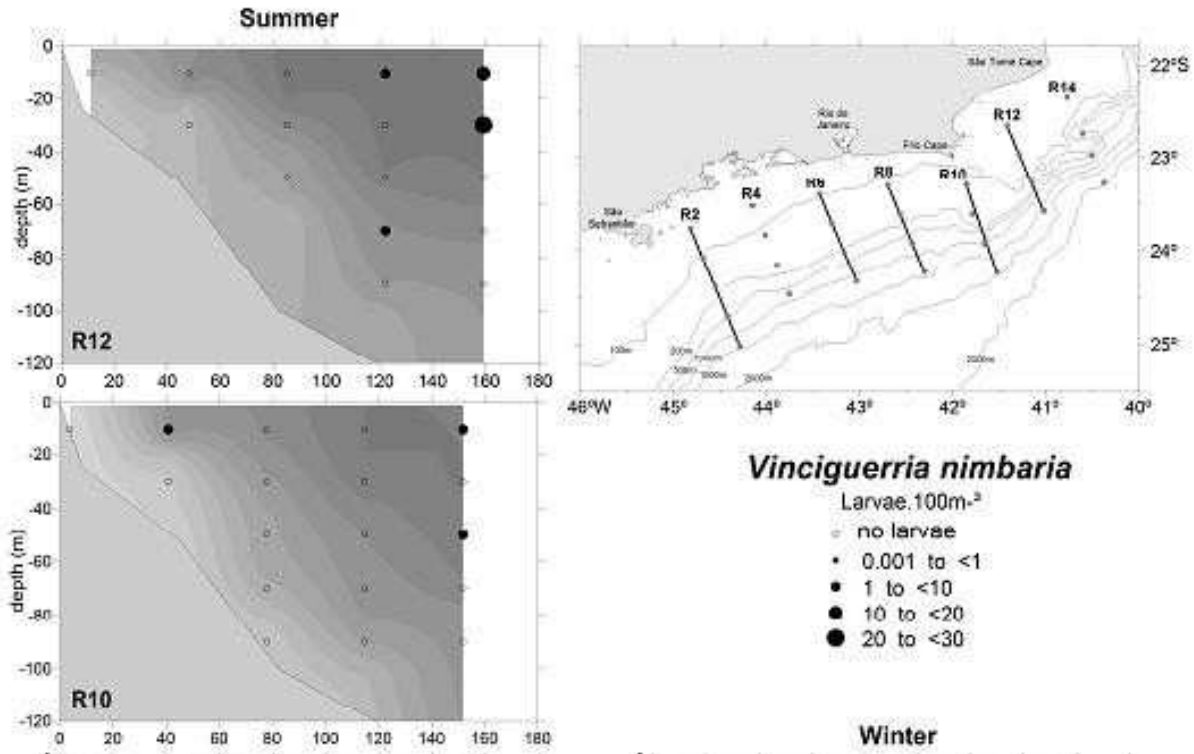

Vinciguerria nimbaria

Larvae. $100 \mathrm{~m}^{2}$

- no larvae

- 0.001 to $<1$

- 1 to $<10$

10 to $<20$

20 to $<30$

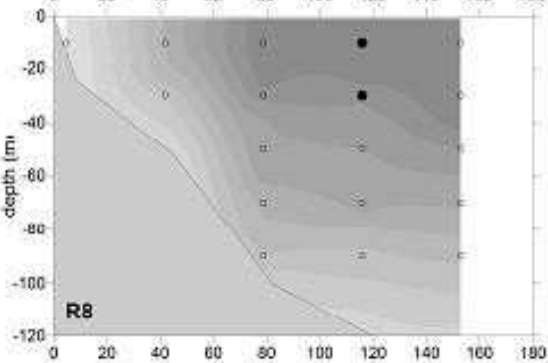

Winter

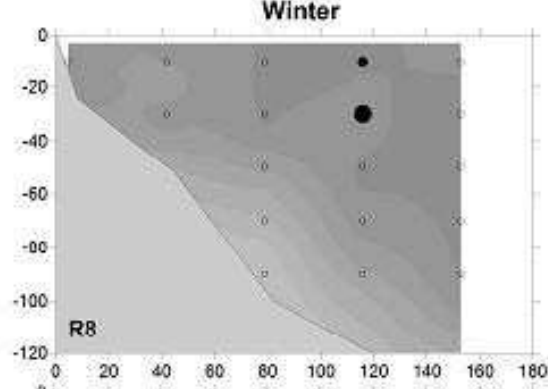
tomporature $\left\{{ }^{\circ} \mathrm{C}\right)$
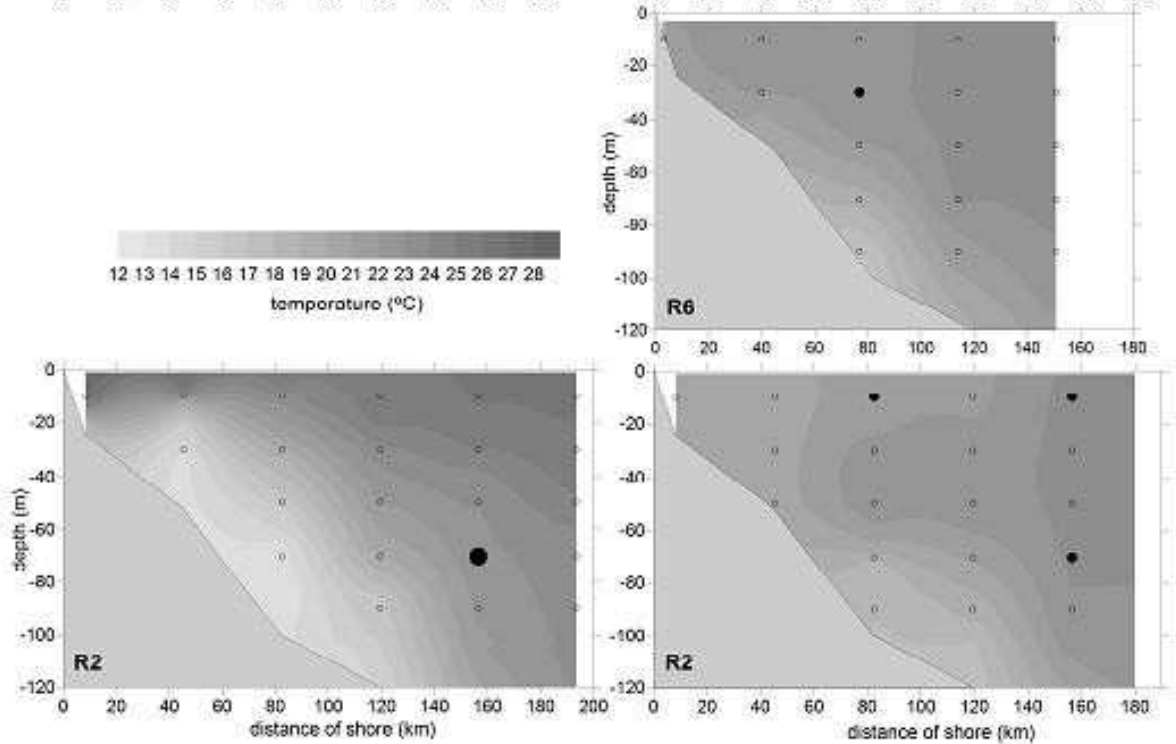

Fig. 6. Vertical profiles of temperature $\left({ }^{\circ} \mathrm{C}\right)$ and vertical distribution of $V$. nimbaria larvae on transect perpendicular to Brazilian coast $(\mathrm{R})$ during the summer and winter, 2002. The density is expressed in larvae. $100 \mathrm{~m}^{-3}$. 
In the water column, $P$. mauli larvae in preflexion were collected more frequently between 40 and $100 \mathrm{~m}$, while, postflexion larvae were more frequent between the surface and $20 \mathrm{~m}$, these data suggesting an ontogenetic vertical movement of larvae (Fig. 8).

The length of $V$. nimbaria larvae ranged from 3 to $23 \mathrm{~mm}$, indicating the presence of all the early stages. More than $45 \%$ of the larvae were in postflexion. The length in the preflexion stage ranged from 3 to $6 \mathrm{~mm} \mathrm{NL}$, and in the flexion stage from 6 to $8 \mathrm{~mm}$ SL. So that specimens $>8 \mathrm{~mm}$ SL were in postflexion. The predominant size classes during the summer in the oceanic sub-area were those of 5.75 and $6.25 \mathrm{~mm}$, and in the intermediate sub-area were of 4.75 and $6.25 \mathrm{~mm}$. During the winter the predominant size classes were of 4.25 and $5.75 \mathrm{~mm}$ in the oceanic region and $4.75 \mathrm{~mm}$ and $6.75 \mathrm{~mm}$ in the intermediate region, but no significant differences were found in the size-frequency larvae among regions in either season (Mann-Whitney U-test, $P>0.05$ ) (Fig. 7). V. nimbaria larvae in preflexion were collected more frequently between 60 and $80 \mathrm{~m}$, while postflexion larvae were
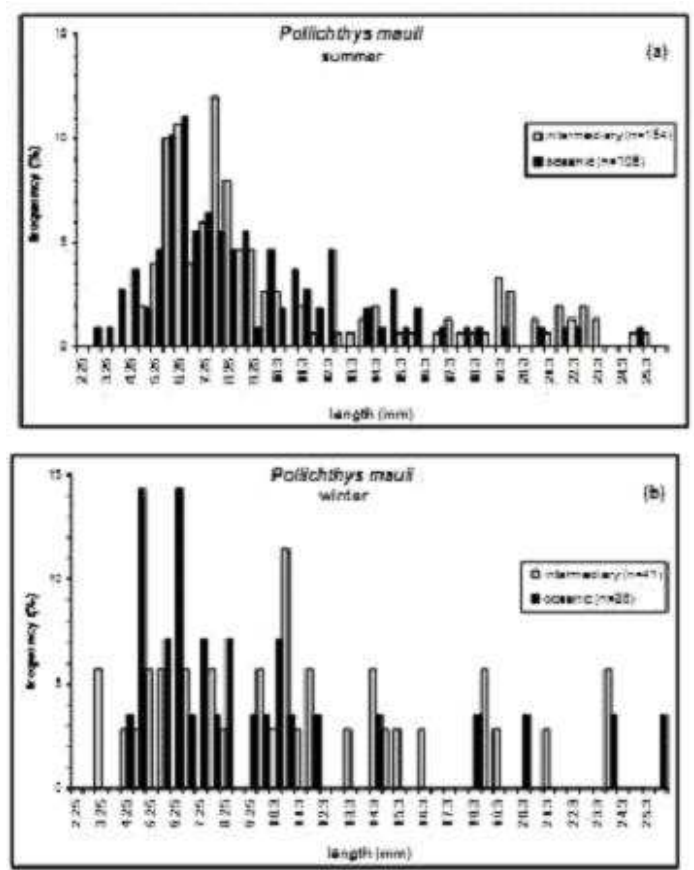

more frequent between the surface and $20 \mathrm{~m}$ and from 20 to $40 \mathrm{~m}$ depth, there being no significant difference in the size-frequency larvae among layers (KruskalWallis test, $P>0.05$ ) and no clear ontogenetic vertical movement because the number of larvae was very low.

\section{Diel Variation}

Larval $P$. mauli occurred during all periods of the day (dawn, day, dusk and night), but $V$. nimbaria was absent at dusk. No significant differences were observed among periods, but abundance was higher at night than in the other periods for the two species in both seasons (KruskalWallis test, $P>0.05$ ).

In the water column, $P$. mauli larvae occurred in higher density in the upper layer $(0-60 \mathrm{~m})$ during the night but in the 60 to $80 \mathrm{~m}$ layer the density was high during the day in the summer and at dawn in the winter. In the deepest layer $(80-100 \mathrm{~m})$ a greater density of larvae was estimated but no significant difference was observed (Kruskal-Wallis test, $P>$ 0.05) (Fig. 9).
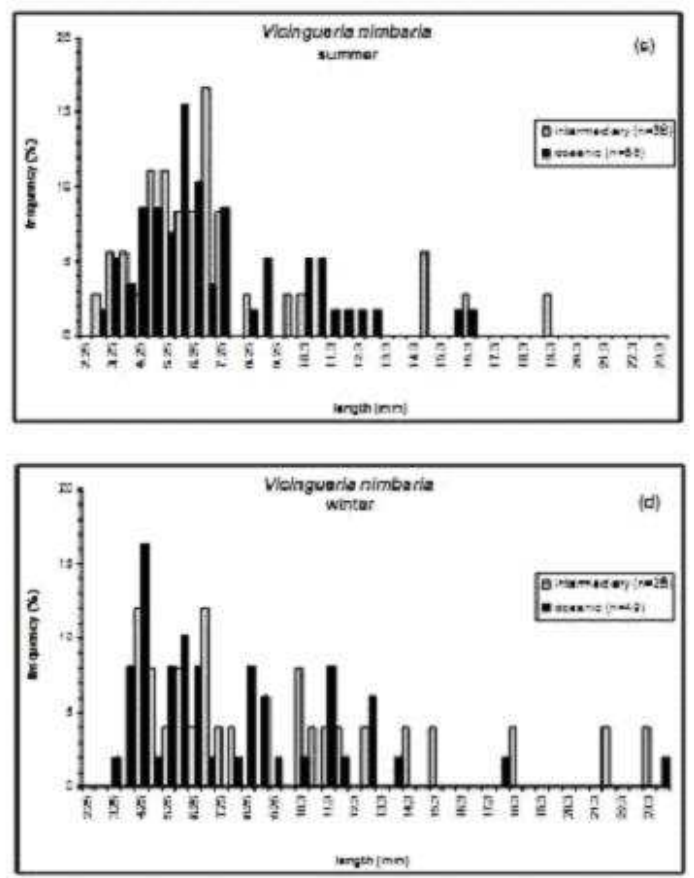

Fig. 7. Frequency - size class distribution of $P$. mauli during the summer (a) and winter (b) and $V$. nimbaria larvae in the summer (c) and winter (d) in the intermediary and oceanic region, in 2002. 


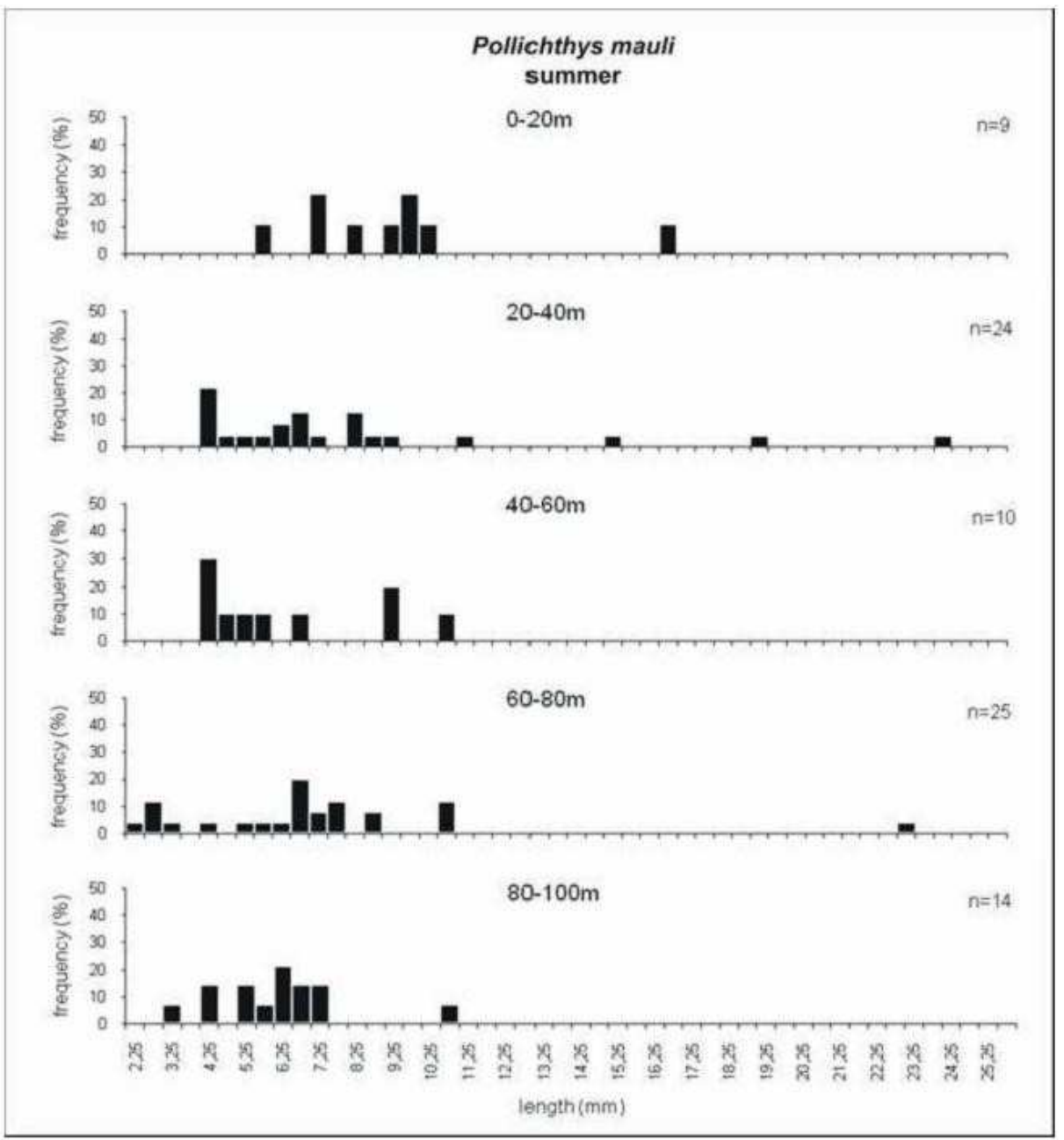

Fig. 8. Frequency - size class distribution of $P$. mauli larvae in the layers sampled by MPS net, during the summer in 2002. The $n$ is the number of larvae collected.

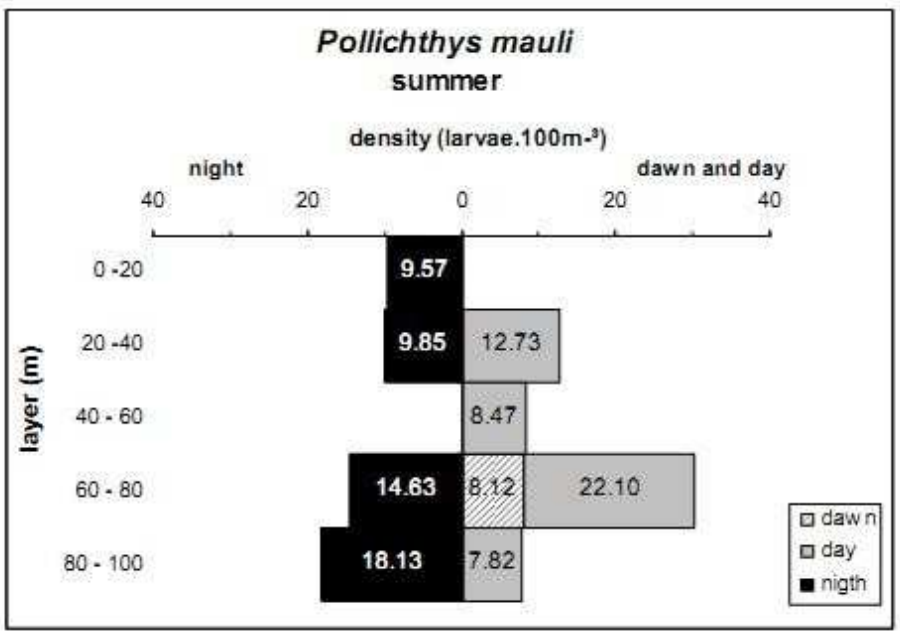

Fig. 9. Vertical distribution of $P$. mauli density larvae (larvae. $\left.100 \mathrm{~m}^{-3}\right)$ in the layers sampled in the periods of the day, during the summer in 2002. 
In the summer, larval stages of $V$. nimbaria were collected during dawn, day and night from the surface to $40 \mathrm{~m}$ but were more concentrated during the day in the 60-80 m layer. The highest larval density was estimated during the day between 20 and $40 \mathrm{~m}$ depth in the winter. No significant differences were found among the densities estimated for any of the layers (Kruskal-Wallis test, $P>0.05$ ) and it was not possible to verify any diel vertical migration.

\section{Environmental and Biological Relationships}

The Redundancy analysis indicated that the seasons and the temperatures (axis 1: $34.5 \%$; axis 2 : $24.4 \%$, respectively) were the most marked determining environment factors in the larval distribution of $P$. mauli and $V$. nimbaria, according to ontogenetic stage and diel variation (Monte Carlo, $P<$ $0.05)$. The diagram of ordination showed a positive correlation between different development stages of $P$. mauli and the summer, when the larval density (larvae. $100 \mathrm{~m}^{-3}$ ) presented its highest values, and a correlation between $V$. nimbaria larvae and the winter, also observed in terms of the values of larval density (Fig. 9).

The preflexion stage of $P$. mauli and $V$. nimbaria presented a positive correlation to depth and a negative one to temperature. Larvae occurred mainly in the deeper layers (40 and $100 \mathrm{~m})$ of the water column analyzed, where the temperature is lower. Postflexion larvae were more frequent between the surface and $20 \mathrm{~m}$ depth, presenting a negative correlation to depth and a positive one to temperature.

In relation to diel variation, both species were collected in greater density during the night on both summer and winter cruises. As $P$. mauli and $V$. nimbaria larvae in the postflexion stage presented a positive correlation to night, while preflexion and flexion larvae presented a negative correlation, we may suppose that the swimming abilities and the change in visual perception related to the stages of larval development, exercise an influence in the capture of the larvae.

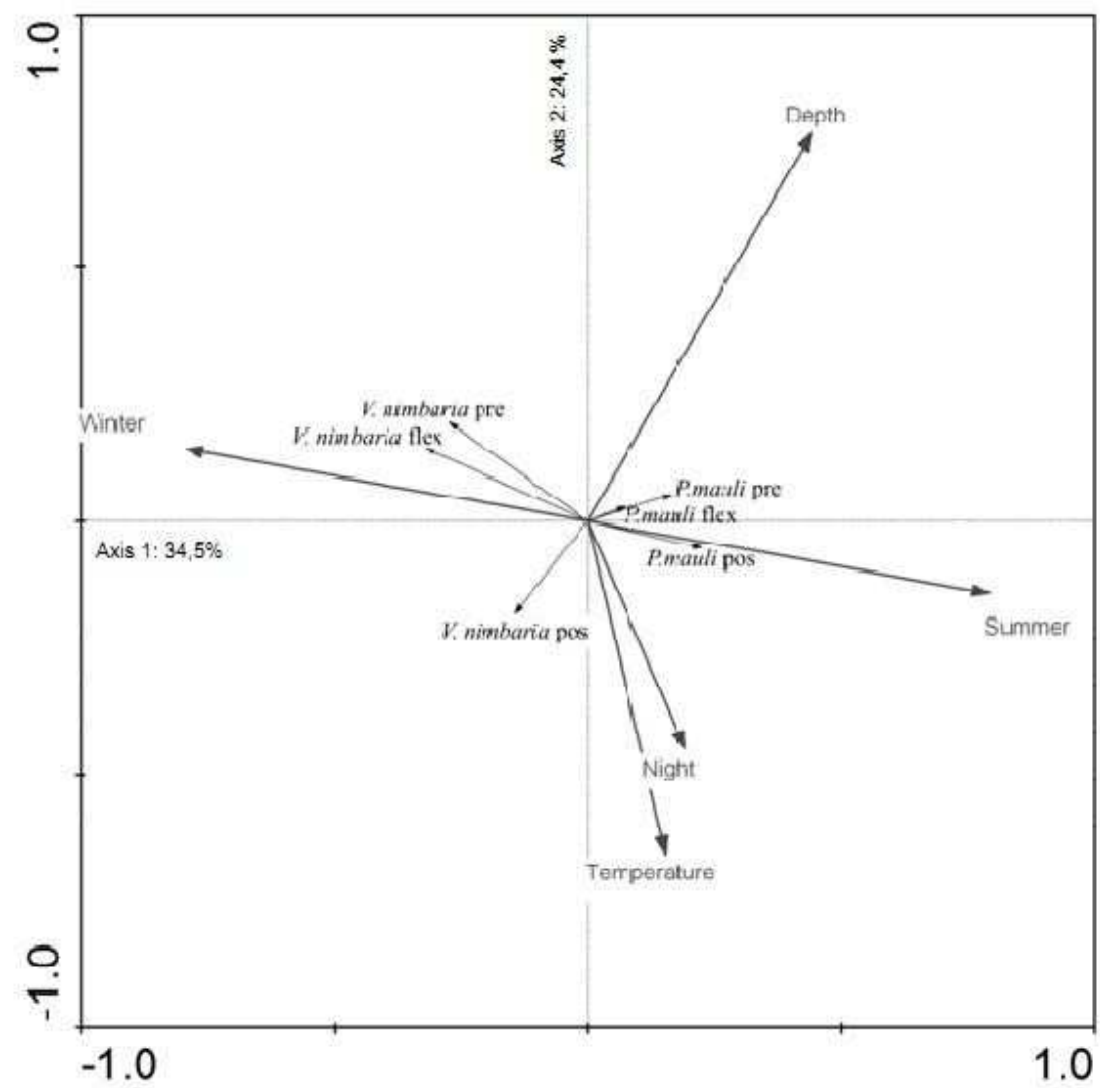

Fig. 10. RDA ordination plot of $P$. mauli and $V$. nimbaria in different development larval stages according to the state of notochord and environment factors that presented significant difference, according to Monte Carlo test $(P<0.05)$. V. nimbaria and $P$. mauli pre $=V$. nimbaria and $P$. mauli in preflexion stage, $V$. nimbaria and $P$. mauli flex $=V$. nimbaria and $P$. mauli in flexion stage and $V$. nimbaria and $P$. mauli pos $=V$. nimbaria and $P$. mauli in postflexion stage. 
Larval $P$. mauli and $V$. nimbaria occurred throughout the study area, presenting their highest abundance values at those oceanographic stations located in the intermediate and oceanic sub-areas and distributed in the upper $100 \mathrm{~m}$ depth of the water column, where the Tropical Water (TW) mass was present. Probably larval distribution is related to the TW transported by the Brazilian Current.

\section{Discussion}

Phosichthyidae species compose the mesopelagic group of fishes in the marine ecosystem but are not the dominant ones. The proportion of Phosichthyidae larvae (ca. $2 \%$ of total larvae collected) was relatively low in the present study, if one compares this result with the relative value of the other mesopelagic fish larvae, such as those of Sternoptychidae ( $c a .15 \%$ ) and Myctophidae (ca. $14 \%)$. However, this low proportion of occurrence of larvae is similar to that observed in other regions, e.g. off eastern Brazil (NONAKA et al., 2000), in the Gulf of California (AVALOS-GARCIA et al., 2003), the western North Pacific (SASSA; KONISHI, 2006) and on the shelf break of the East China Sea (OKAZAKI; NAKATA, 2007).

Although eight species of Phosichtyidae are known to inhabit southeastern Brazilian waters (MENEZES; FIGUEIREDO, 2003), only three species, Pollichthys mauli (POLL, 1953), Vinciguerria nimbaria (JORDAN and WILLIAMS, 1895) and Ichthyococcus sp., were collected in the present study. The sampling method may influence the collection of some species due to the vertical migration to layers deeper than those attained by the bongo net. But studies indicate that the majority of fish larvae, even of the mesopelagic species, are distributed in the upper $200 \mathrm{~m}$ of the water column (e.g. LOEB, 1980; BRODEUR; RUGEN, 1994; SASSA et al., 2002). Larval Ichthyioccoccus $s p$., that was extremely rare in the samples, is exceptional as it inhabits depths of from 200 to $500 \mathrm{~m}$ (SCHAEFER et al., 1986). According to BERNARDES et al. (2005), adult Vinciguerria poweriae and Polymetme thaeocoryla tend to be distributed in the southernmost Brazilian waters, far from the area of this present study. Perhaps the same pattern of geographical distribution of the larvae may explain the absence of these species in our results.

Larvae of $P$. mauli and $V$. nimbaria have been registered, by many authors, in the Atlantic, Pacific and Indian Oceans (SCHAEFER et al., 1986; RICHARDS, 2006; OKAZAKI; NAKATA, 2007; MOYANO et al., 2009, among others). In Brazilian waters these species have previously been reported on the eastern coast by BONECKER AND HUBOLD (1990). Both these species occurred in summer and winter in the present study, but the occurrence of these larvae has also been reported in spring by BONECKER and HUBOLD (1990), and in autumn by NONAKA et al. (2000), suggesting that these species spawn all the year round.

Overall, abundance did not differ significantly between seasons for $P$. mauli or $V$. nimbaria larvae, but a slight trend to higher abundance was observed for both species in the summer. This result agrees with BADCOCK (1984) who observed a spawning peak of $P$. mauli during the summer in the Western North Atlantic and the Mediterranean Sea. On the other hand, STEQUERT et al. (2003) reported that $V$. nimbaria larvae are predominant all the year round and that this species spawns continuously throughout the year in the equatorial Atlantic Ocean.

Our results showed that the pattern of vertical distribution of $P$. mauli larvae differed with season, being widespread in all layers in the summer, but with a higher density in the 60-80 $\mathrm{m}$ layer, whereas in the winter larvae tended to concentrate in the 40-60 $\mathrm{m}$ layer. But the distribution of $V$. nimbaria did not overlap that of the former species and exhibited a preference for the $20-40 \mathrm{~m}$ layer both in the summer and in the winter. Muhling and Beckley (2007) undertook collections in south-western Australia from the surface to $1000 \mathrm{~m}$ depth; Pollichthys sp. larvae were caught only at $1000 \mathrm{~m}$ depth during the winter and Vinciguerria sp. were collected in layers below $40 \mathrm{~m}$, and in greater density at $300 \mathrm{~m}$ depth. V. nimbaria larvae were collected in layers deeper than $50 \mathrm{~m}$ in the North Atlantic (GREY, 1964) and LOEB (1979, 1980) observed more occurrences of larvae (90\%) between 25 and $75 \mathrm{~m}$ depth and collected the highest number of $V$. nimbaria larvae between 25 and $50 \mathrm{~m}$ in the North Pacific central gyre.

Diel vertical migration is known to occur in several groups of fish and their larvae, especially in species with light organs (CLARKE, 1971; NEILSON; PERRY, 1990; WATANABE et al., 1999). Our results indicated a tendency of $P$. mauli larvae to concentrate in the surface layer $(0-20 \mathrm{~m})$ during the night, and to occur in higher density in the 60-80 m layer during the day, indicating a movement of organisms in the water column during the day, but some larvae were observed at $80-100 \mathrm{~m}$ both at night and by day. This diel movement was not clear with regard to $V$. nimbaria larvae, but a vertical migration of adult $V$. nimbaria related to its feeding activity is known (MARCHAL and LEBOURGES, 1996; LEBOURGES-DHAUSSY et al., 2000; STEQUERT et al., 2003), so further studies are necessary to enable us to come to a conclusion regarding the behavior of V. nimbaria larvae.

Postflexion larvae were mainly associated with the night period, whereas preflexion and flexion 
larvae were associated with other periods of the day. This fact may be related to the increase in the ability to move associated with growth. Postflexion larvae have greater swimming ability and are capable of migrate vertically, rising to the surface at night and descending to deeper layers during the day. Net avoidance associated with the development of the visual perception of the larvae (BLAXTER; HUNTER, 1982) may also have had some influence in the sampling of larger specimens during the day. SASSA and KONISH (2006) observed no clear ontogenetic vertical migration of jack mackerel larvae (Trachurus japonicus) with $<3 \mathrm{~mm}$ standard length. According to those authors, migratory behavior tends to develop with the increased swimming ability of the larvae and greater intensity is observed in the vertical migration after the postflexion stage.

In the present study the early larval $P$. mauli (by $3 \mathrm{~mm} \mathrm{NL}$ ) was concentrated in the deeper layer $(60-80 \mathrm{~m})$ of the oceanic sub-area, whereas the postflexion larvae were found mainly near the surface $(0-40 \mathrm{~m})$ and in the intermediate sub-area. The postflexion larvae of $V$. nimbaria also had their peak distribution in the intermediate sub-area and in the surface $(0-20 \mathrm{~m})$ layer. The occurrence of preflexion larvae in layers deeper than $60 \mathrm{~m}$ was also observed by LOEB (1979) in the North Pacific Central gyre. These patterns of vertical distribution related to ontogeny may be strategically important to development during the early life stages, as food requirements, as well as the ability to detect prey, increase with the size of the larvae. In this case the presence of larger larvae in the upper surface layer, with higher prey abundance, must be advantageous for feeding. On the other hand, changes in oceanographic conditions, which vary according to the different layers of the water column, may affect the larval stages in other ways, for example by transporting them to more or less favorable areas (CHA et al., 1994).

The larval phosichthyids were, in some case, found in the TW-SACW interface. This pattern of distribution associated with the transition area of two water masses has also been observed in other regions. LOEB $(1979,1980)$ studying the vertical distribution of Vinciguerria collected in the mixing layer and Ahlstrom (1959) collected V. lucetia larvae in the mixed layer and above the thermocline in Baja California. In Brazil, BONECKER and HUBOLD (1990), observed the occurrence of $V$. nimbaria and Vinciguerria sp. associated with the mixture between TW and SACW.

Several works have shown that phosichthyids are distributed mainly in the oceanic region (e.g. OKAZAKI; NAKATA, 2007; MOYANO et al., 2009), although distribution in a shallower zone (50-100 $\mathrm{m}$ isobaths) has been reported in eastern Brazil (BONECKER; HUBOLD, 1990; NONAKA et al., 2000; BONECKER et al., 2006). In the case of the present study the environmental boundaries of both species appear to be in close association with the Tropical Water (TW), that embraces the oceanic but also the neritic area, at least as far as the mid-shelf. The overall picture of the present study area, from the hydrographic point of view, follows the classical description given in the literature for both seasons (CASTRO; MIRANDA, 1998; SILVEIRA et al., 2000; CASTRO et al., 2006; among others) and shows the interactions of the three water masses, TW, SACW, and CW. The shapes of the T-S diagrams of this study (Fig. 3) resemble the shape of those described by CASTRO and MIRANDA (1998) based on historical data. Among the many hydrographic features of the Southeastern Brazilian Bight, the perturbations of the Brazil Current flow in the form of meanders or eddies seem to be crucial to the spreading of the larvae of mesopelagic fish over the neritic area.

As the presence of early larvae indicates the proximity of the spawning ground (JONES, 2002), the spawning of $P$. mauli and $V$. nimbaria is probably concentrated in the deeper layers of the water column of the oceanic area, where the early larvae were found. After hatching, the larvae tended to expand their distribution, either vertically or geographically, as discussed above. Our findings that both species exhibited increased mean lengths in an offshorecoastal direction, supports the idea of their moving to the neritic area. This distribution must be favored by the meandering patterns or eddy activities (CASTRO; MIRANDA, 1998) which enhance the transport of larvae toward the mid-shelf. One of the benefits to the species is that, as the demand for food increases with larval growth, the movement from oligotrophic oceanic water to areas of higher concentration of prey organisms may contribute to the improvement of the larval condition as also therefore to the chance of success in surviving during early development.

The larval transport strategy, from oligotrophic to productive regions, has been accounted as important for mesopelagic species in other regions. For example, in an analysis of distribution patterns of larval myctophids in the transitional region of the western North Pacific, SASSA et al. (2004) discussed the role of hydrographic structures, such as the fronts and rings related to the Kuroshio and Oyashio current systems, in larval transport from spawning to nursery grounds. Concerning the phosichthyids of Southeastern Brazil, further studies are necessary to obtain information such as will enable us accurately to correlate the increment of age to distance offshore, as well as information on the speed at which those fish larvae can be transported within the system, in order to evaluate the use of the area as a nursery ground.

Another hydrographic feature important to the biological processes in southeastern Brazilian 
waters is the intrusion of the SACW toward the coast in the bottom layer. The position of the bottom thermal front changes seasonally, being closer to the coast during summer and farther offshore during winter (CASTRO; MIRANDA, 1998), and depending on the strength of the SACW intrusion the coastal upwelling may occurs, mainly near Frio cape. The spawning strategies associated with these dynamic processes have already been intensively discussed (MATSUURA, 1996; LOPES et al., 2006), and it has been observed that the input of the nutrient rich cold water of the SACW contributes to the enhancement of primary productivity in the coastal area (LOPES et al., 2006). For some small pelagic fish species, such as sardine and rough scad, studies have shown a tendency of the peak spawning period to correspond to the period when the intrusion of SACW becomes more frequent, i.e., during spring and summer (MATSUURA et al., 1992; KATSURAGAWA et al., 2006). However, for the phosichthyids of the study area, apparently there is no direct dependence on the coastal events as no significant difference in larval abundance between summer and winter has been found, but rather these species seem to be opportunistic in taking advantage of the eddies as a way to spread throughout the neritic area, and thus improve the chance of finding the prey organisms. Further studies comparing the nutritional conditions of larvae collected in oceanic and coastal areas may contribute to an evaluation of the advantage of this distribution pattern.

\section{ACKNOWLEDGMENTS}

We wish to express our thanks to IOUSP the Instituto Oceanográfico da Universidade de São Paulo as also to the Brazilian agency CNPq (Conselho Nacional de Desenvolvimento Científico e Tecnológico) for the financial support given for this investigation and the scholarship granted during this study by CAPES (Coordenação de Aperfeiçoamento de Pessoal de Nível Superior). Our thanks are also due to the crew of the R/V "Prof. W. Besnard" for their assistance in the collecting of samples and to Maria de Lourdes Zani-Teixeira for her continuous technical assistance in the preparation of this manuscript.

\section{REFERENCES}

AHLSTROM, E. H. Vertical distribution of pelagic fish eggs and larvae off California and Baja California. Fishery Bull., U.S., v. 60, p. 107-146, 1959.

AHLSTROM, E. H.; BALL, O. P. Description of eggs and larvae of jack mackerel (Trachurus symmetricus) and distribution and abundance of larvae in 1950 and 1951. Fishery Bull., U.S., v. 56, p. 209-245, 1954.

AHLSTROM, E. H.; COUNTS, R. C. Development and distribution of Vinciguerria lucetia and related species in the eastern Pacific. Fishery Bull.,U.S. v. 58, p. 359409,1958 .

AVALOS-GARCIA， C.; SÁNCHEZ-VELASCO， L.; SHIRASAGO, B. Larval fish assemblages in the Gulf of California and their relation to hydrographic variability (autumn 1997-summer 1998). Bull. mar. Sci., v. 72, n. 1, p. 63-76, 2003.

BADCOCK, J. Photichthyidae. In: WHITEHEAD, P. J. P.; BAUCHOT, M. L.; HUREAU, J. C.; NIELSEN, J.; TORTONESE, E. (Ed.). Fishes of the North-Eastern Atlantic and the Mediterranean. v. 1. Paris: UNESCO, 1984, p. $318-324$

BERNARDES, R. A.; FIGUEIREDO, J. L. DE; RODRIGUES, A. R FISCHER, L. G.; VOOREN, C. M.; HAIMOVICI, M.; ROSSI-WONGTSCHOWSKI C. L. D. B. Peixes da Zona Econômica Exclusiva da Região Sudeste-sul do Brasil: Levantamento com armadilhas, pargueiras e rede de arrasto de fundo. São Paulo: EDUSP, 2005. p. $119-121$.

BLAXTER, J. H. S. Monitoring the vertical movements and light responses of herring and plaice larvae. J. mar.biol. Ass. U.K., v. 53, p. 635-647, 1973.

BLAXTER, J.H.S; HUNTER, J. R. The Biology of the Clupeoid fishes. New York: Academic Press, 1982. 223 p. (Advances in Marine Biology, v. 20).

BONECKER, A. C. T; HUBOLD, G., Distribution and abundance of larval gonostomatid fishes in the southwest Atlantic. Meeresforschung, v. 33, p. 38-51, 1990.

BONECKER, F. T.; BONECKER, A. C. T; CASTRO, M. S.; NAMIKI, C. A. P.; BARROS, F. B. A. G. Stomiiformes: Gonostomatidae, Sternoptychidae, Phosichthyidae e Stomiidae. In: BONECKER, A. C. T.; CASTRO, M. S. (Ed.). Atlas de larvas de peixes da região central da Zona Econômica Exclusiva Brasileira. Rio de Janeiro: Museu Nacional, 2006. p. 86 - 87.

BRODEUR, R. D.; RUGEN, W. C. Diel vertical distribution of ichthyoplankton in the Gulf of Alaska. Fishery Bull.,U.S. v. 92, p. 223-235, 1994.

CASTRO, B. M.; MIRANDA, L. B. Physical oceanography of the western Atlantic continental shelf located between $4^{\circ} \mathrm{n}$ and $34^{\circ} \mathrm{s}$. In: ROBINSON, A. R.; BRINK, K. H. (Ed.). The global coastal ocean: regional studies and syntheses. New York: John Wiley, 1998. p. 209-251. (The sea, v. 11).

CASTRO, B. M.; LORENZETTI, J.A.; SILVEIRA, I. C. A DA; MIRANDA, L. B. Estrutura termohalina e circulação na região entre o cabo de São Tomé (RJ) e o Chuí (RS). In: ROSSI - WONGTSCHOWSKI C. L. D. B.; MADUREIRA L. S. P. (Org.). O Ambiente oceanográfico da Plataforma Continental e do Talude na região sudeste-sul do Brasil. São Paulo: Edusp, 2006. p. $11-120$.

CHA, S. S.; MCGOWAN, M. F.; RICHARDS, W. J. Vertical distribution of fish larvae off the Florida keys, 26 may 5 June 1989. Bull. mar. Sci., v. 54, n. 3, p. 828-842, 1994.

CLARKE, G. L. Light conditions in the sea in relation to the diurnal vertical migrations of animal). In: FARQUAAR, G. B. (Ed.). Proceedings of the INTERNATIONAL SYMPOSIUM ON BIOLOGICAL SOUND SCATTERING IN THE OCEAN. Washington,DC: Maury Center Ocean Science, 1971. p. 41-50. Cited in: MARCHAL E.; LEBOURGES, A. Acoustic evidence for unusual diel behavior of a mesopelagic fish 
(Vinciguerria nimbaria) exploited by tuna. ICES J mar.Sci., v. 53, p. 443-447, 1996.

EMÍLSSON, I. The shelf and coastal waters off southern Brazil. Bolm Inst. oceanogr., São Paulo, v. 11, n. 2, p. 101-112, 1961.

FAHAY, M. P. Guide to the Early Stages of Marine Fishes occurring in the Western North Atlantic Ocean, Cape Hetteras to southern Scotia shelf. J. Northwest Atl. Fish. Sci., v. 4, p. 72-79, 1983.

FAHAY, M. P. Early stages of fishes in the Western North Atlantic Ocean, Davis Strait, Southern Greenland and Flemish Cap to Cape Hatteras. 2007. p. 306-351.

FORTIER, L.; LEGGETT, W. C. Vertical migrations and transport of larval fish in a partially mixed estuary. Can. J. Fish. Aquat. Sci., 1983. v. 40, p. 1543 - 1555, 1983. -Cited in: CHA, S.S.; MCGOWAN, M.F. RICHARDS, W.J. Vertical distribution of Fish Larvae off the Florida Keys, 26 May - 5 June 1989. Bull. Mar. Sci., v. 54 n. 3, p. 828-842, 1994

FUKUI, A.; KURODA, H. Larval and Juvenile Polymetme elongata (Stomiiformes: Phosichthyidae) collected from Suruga Bay and offshore Waters, Japan. Ichthyol. Res., v. 52, p. 396-400. 2005.

GREY, M. Family Gonostomatidae. In: BIGELOW, H. B. (Ed.). Fishes of the Western North Atlantic. Mem. Sears Fdn mar. Res., v. 1, Pt. 4, p. 78-240, 1964.

GUILLE A. Benthic Bionomy of Continental Shelf of French Catalane Coast. Ii. Benthic Communities of the Macrofauna. Vie Millieu, v. 21, n. 8, p. 149-280, 1970.

HEMPEL, G. Early life history of marine fish (The Egg Stage). Seattle: University of Washington Press, 1979. $70 \mathrm{p}$.

HENSEN, V. Uber die Bestimmung des Planktons oder des im Meere treibenden Materials an Pflanzen und Thieren. V. Bericht d. Kom. z. wiss. Unters. D. deutschen Meere, 1887.v. 12-16, p. 1-108. Cited in: In: HARRIS R. P., WIEBE, P. H., LENZ, J., SKJOLDAL, H. R.; HUNTLEY M. (Ed). ICES Zooplankton methodology Manual. Bodmin, Cornwall: MPG Books, 2000. 684 p.

JOHN, H.-CH; LUTJEHARMS, J.R.E; MOHRHOLZ, V. Cross-front hydrography and fish larval distribution at the Angola-Benguela Frontal Zone. J mar Syst., v. 28, p. 91-111, 2001

JONES, C. M. Age and Growth. In: FUIMAN, L; WERNER. R.G. (Ed.). Fishery Science - The unique contributions of early life stages. Blackwell Science , 2002. p. $33-63$.

KATSURAGAWA, K.; MATSUURA, Y. Distribution and abundance of carangid larvae in the southeastern Brazilian Bight during 1975-1981. Bolm Inst. oceanogr., São Paulo, v. 40, n. 1/2, p. 55-78, 1992.

KATSURAGAWA, M.; MUELBERT, J.H.; DIAS, J. F. O Ictioplâncton na região entre o Cabo de São Tomé (Rj) e o Chuí (Rs). In: ROSSI - WONGTSCHOWSKI C. L. D. B.; MADUREIRA L. S. P. (Org.). O ambiente oceanográfico da Plataforma Continental e do Talude na Região sudeste-sul do Brasil. São Paulo: Edusp, 2006. p. 359 - 446.

LASKER, R. Field criteria for the survival of Anchovy Larvae: the relation between inshore chlorophyll maximum layers and successful first feeding. Fishery Bull., U.S., v. 73, n. 3, p. 453-462, 1975.

LEBOURGES-DHAUSSY, A.; MARCHAL, E.; MENKÈS, C.; CHAMPALBERT, G.; BIESSY, B. Vinciguerria nimbaria (micronekton), environment and tuna: their relationships in the Eastern Tropical Atlantic. Oceanol. Acta, v. 23 n. 4, p. 515-527, 2000.

LERMAN, M. Marine Biology: Environment, diversity, and Ecology. Menlo Park, The Benjamin/Cummings Publ., 1986. $534 \mathrm{p}$

LOEB, V. J. Vertical Distribution and Development of Larval Fishes in the North Pacific Central Gyre during summer. Fishery Bull, U.S., v. 77, n. 4, p. 777-793, 1979

LOEB, V. J. Patterns of spatial and species abundance within the larval fish assemblage of the North Pacific Central Gyre during late summer. Mar. Biol. v. 60, p. 189-200, 1980.

LOPES, R. M; KATSURAGAWA, M.; DIAS, J. F.; MONTÚ, M. A.; MUELBERT, J. H.; GORRI, C.; BRANDINI, F. P. Zooplankton and ichthyoplankton distribution on the Southern Brazilian Shelf: An overview. Scient. Mar., v. 70, n. 2, p. 189-202, 2006.

MARCHAL, E.; LEBOURGES, A. An acoustic evidence for unusual diel behavior of mesopelagic fish (Vinciguerria nimbaria) exploited by tuna. Ices J. mar. Sci., v. 53, p. 443-447, 1996.

MATSUURA, Y. A probable cause of recruitment failure of the Brazilian sardine Sardinella aurita population during the 1974/75 spawning season. S. Afr. mar. Sci., v.17, p. $29-35,1996$

MATSUURA, Y.; NAKATAMI, K.; TAMASSIA, S. T. J. Distribuição Sazonal de Zooplâncton, Ovos e Larvas de Peixes na Região Centro-Sul do Brasil (1975-77). Bolm Inst. oceanogr., São Paulo. v. 29, n. 2, p. 231-235, 1980.

MATSUURA Y.; SPACH, H. L.; KATSURAGAWA, M. Comparison of Spawning Patterns of Brazilian Sardine (Sardinella brasiliensis) and Anchoita (Engraulis anchoita) in Ubatuba Region, Southern Brazil during 1985 through 1988. Bolm Inst. oceanogr., São Paulo, v. 40, p. 101-115, 1992.

MENEZES N. A; FIGUEIREDO, J. L. Phosichthyidae. In: MENEZES N.A.; BUCKUP, P. A.; FIGUEIREDO, J. L.; MOURA, R. L. De. Catálogo das espécies de peixes marinhos do Brasil. São Paulo: Museu de Zoologia da Universidade de São Paulo, 2003. 159 p.

MIRANDA, L. B. Forma de correlação T-S de massas de água das regiões costeiras e oceânicas entre o cabo de São Tomé (RJ) e ilha De São Sebastião (SP), Brasil. Bolm Inst. oceanogr., São Paulo. v. 33, n. 2, p. 105119, 1985.

MOTEKI, M.; ARAI, M.; TSUCHIYA, K.; OKAMOTO, H. Composition of piscine prey in the diet of large pelagic fish in the eastern Tropical Pacific Ocean. Fish. Sci.. v. 67, p. 1063 - 1974, 2001.

MOYANO, M.; RODRÍGUEZ, J. M; HERNÁNDEZ-LEÓN, $\mathrm{S}$. Larval fish abundance and distribution during the late winter bloom off Gran Canaria Island, Canary Islands. Fish. Oceanogr., v. 18, n. 1, p. 51-61, 2009.

MUHLING, B.A.; BECKLEY, L.E. Seasonal variation in horizontal and vertical structure of larval fish assemblages off southwestern Australia with implications for larval transport. J. Plankt. Res., v. 29, n.11, p. 967-983, 2007.

NEILSON, J. D.; PERRY, R. I. Diel vertical migrations of juvenile fish: an obligate or facultative process? Adv. mar. Biol., v. 26, p. 115-168, 1990 
NONAKA, R. H., MATSUURA, Y, SUZUKI, K. Seasonal variation in larval fish assemblages in relation to oceanographic conditions in the Abrolhos Bank region off eastern Brazil. Fishery Bull., U. S., v. 98, p. 767784,2000

OKAZAKI Y.; NAKATA, H. Effect of the Mesoscale Hydrographic Features on Larval Fish Distribution Across the Shelf Break of East China Sea. Continent. Shelf. Res., v. 27, p. 1616 - 1628, 2007.

OZAWA, T. Early Life History of the Gonostomatid Fish, Pollichthys mauli, in the Oceanic Region off Southern Japan. Jpn. J. Ichthyol., v. 23, p. 43-54. Cited in: FUKUI, A.; KURODA, H. Larval and Juvenile Polymetme elongata (Stomiiformes: Phosichthyidae) collected from Suruga Bay and offshore Waters, Japan. Ichthyol. Res., v. 52, p. 396-400, 2005.

PHONLOR, G. Morfologia e Biologia de larvas de Engraulis anchoita (Hubbs \& Marini), (Osteichthyes, Engraulidae). Atlântica, v. 7, p. 85-98, 1984.

RICHARDS, W. J. Phosichthyidae. In: RICHARDS, W. J. early stages of Atlantic fishes: An identification guide for the Western Central North Atlantic. Press Taylor \& Francis Group, 2006. p. 247 - 265.

RODRÍGUEZ J. M., BARTON, E. D., S. HERNÁNDEZLEÓN, ARISTEGUI J. The influence of mesoscale physical processes on the larval fish community in the Canaries CTZ, in summer. Prog. Oceanogr., v. 62, p. 171-188, 2004.

SANZO, L. Uova, Sviluppo Embrionale, Stadi Larvali, Post Larvali E Giovanili Di Sternoptychidae E Stomiatidae. Sternoptychidae. 2 Ichthyococcus Ovatus Cocco. R. Com. Talassogr. Ital. Monogr., v. 2, p. 69-119, 1930. Cited in: MOSER, H. G. The early stages of fishes in the California Current Region. Calcofi., v. 33, p. 284-293, 1996.

SANZO, L. Sottordine: Stomiatoidei. Uova Larve E Stadi Giovanili Di Teleostei. Fauna Flora Golfo Napoli Monogr., 1931. Cited in: MOSER, H. G. The early stages of fishes in the California Current Region. Calcofi, v. 33, p. 284-293, 1996.

SASSA, C.; KONISHI, Y. Vertical distribution of jack mackerel Trachurus Japonicus larvae in the Southern part of the East China Sea. Fish. Sci., v. 72, p. 612-619, 2006.

SASSA, C.; MOSER, H.G; KAWAGUCHI, K. Horizontal and vertical distribution patterns of larval myctophidae fishes in the Kuroshio Current region. Fish. Oceanogr., v. 11, n. 1, p. 1-10, 2002

SASSA, C.; KAWAGUCHI, K.; OOZEKI, Y.; KUBOTA, H; SUGISAKI, H. Distribution patterns of larval myctophidae fishes in the transition region of the western North Pacific. Mar. Biol., v. 144, p. 417-428, 2004.

SCHAEFER, S.; JOHNSON, R.K.; BADCOCK, J. Photichthyidae. In: SMITH M. M.; HEEMSTRA, P. C. (Ed.). Smiths sea fishes. Berlin: Springer-Verlag, 1986. p. $243-247$.
SILVEIRA, I. C. A. da; SCHMIDT, A. C. K.; CAMPOS, E. J. D.; GODOI, S. S. de; IKEDA, Y. A Corrente do Brasil ao Largo da Costa Leste Brasileira. Rev. Bras. Oceanogr., v. 48, n. 2, p. 171-183, 2000.

SMITH, P.E.; RICHARDSON, S.L. Standard techniques for pelagic fish egg and larva surveys. Fao Fish. tech. Pap., v. 175 , p. 1-100, 1977.

STEQUERT, B.; MENARD, F.; MARCHAL, E. Reproductive Biology of Vinciguerria Nimbaria in the equatorial waters of the Eastern Atlantic Ocean. J. Fish. Biol. 2003. v. 62, p. 1116-1136, 2003.

TANAKA, S. Stock assessment by means of ichthyoplankton surveys. Fao Fish. tech. Pap., v. 122, p. 33-51, 1973.

TER BRAAK, C. J. F.; SMILAUER, P. Canoco Reference Manual and Canodraw for Windows User's Guide: Software for canonical community ordination (Version 4.5). Ithaca, NY.: Microcomputer Power, 2002. 500 p. Cited in: LEPS, J.; SMILAUER P. Multivariate analysis of ecological data using Canoco. Cambridge: University Press, 2005. 268 p.

TORTONESE, E. Fauna D'italia, Vol. X, Osteichthyes, Part 1. Calderini, Bologna, 1970. 565 p. In: CUTTITTA, A.; ARIGO, A.; BASILONE, G.; BONANNO, A.; BUSCAINO, G.; ROLLANDI, L.; GARCIA LAFUENTE, J.; GARCIA, A.; MAZZOLA, S.; PATTI, B. Mesopelagic fish larvae species in the Strait of Sicily and their relationships to main oceanographic events. Kluver Academic Publishers. Hydrobiologia, v. 527, p. 177-182, 2004.

WATANABE, H; MOKU, M.; KAWAGUCHI, K.; ISHIMARU, K.; OHNO, A. Diel vertical migration of myctophid fishes (Family Myctophidae) in the transitional waters of the western North Pacific. Fish. Oceanogr. v. 8, n. 2, p. 115-127, 1999.

WATSON, W. Phosichthyidae: Lightfishes. In: MOSER, H.G. The early stages of fishes in the California Current region. Calcofi Atlas, v. 33, p. 284-293, 1996.

ZAR, J. H. Bioestatistical Analyses. 4a ed. Upper Saddle River: Prentice Hall, 1999. 663 p.

ZAVALA-CAMIM, L. A. Alguns aspectos sobre la estructura populacional delrabil (Thunnus Albacares) en el Sudeste y sur del Brasil, com presentación de la hipótesis de la migración semestral. Bolm Inst. Pesca, S Paulo, v. 5, n. 1, p. 1-25, 1978.

(Manuscript received 06 September 2010; revised 18 January 2011; accepted 05 May 2011) 